\title{
Translational preclinical research may lead to improved medical management of non-arteritic anterior ischemic optic neuropathy
}

\author{
James D. Nicholson ${ }^{1,2}$, Hana Leiba ${ }^{3,4}$ and Nitza Goldenberg-Cohen ${ }^{1,2,5 *}$ \\ ${ }^{1}$ The Krieger Eye Research Laboratory, Felsenstein Medical Research Center, Petach Tikva, Israel \\ 2 Sackler Faculty of Medicine, Tel Aviv University, Tel Aviv, Israel \\ ${ }^{3}$ Department of Ophthalmology, Kaplan Medical Center, Rehovot, Israel \\ ${ }^{4}$ Hebrew University Hadassah Medical Center, Jerusalem, Israel \\ ${ }^{5}$ Pediatric Ophthalmology Unit, Schneider Children's Medical Center of Israel, Petach Tikva, Israel \\ ${ }^{*}$ Correspondence: ncohen1@gmail.com
}

Edited by:

Mohammad Hosein Nowroozzadeh, Shiraz University of Medical Sciences, Iran

Reviewed by:

Sharon Tow, Singapore National Eye Centre, Singapore

Beau B. Bruce, Emory University, USA

Keywords: ischemic optic neuropathy, animal models, treatment, AION, non arteritic

Ischemic optic neuropathy is a major cause of significantly reduced vision (1-3). It may be arteritic (AAION) or non-arteritic (NAAION), anterior or posterior. NA-AION, the most common form (1-4), is characterized clinically by acute, monocular, painless visual loss with optic disk swelling (5). It is attributed to an ischemic insult to the optic nerve followed by an inflammatory reaction $(6,7)$. The optic nerve head $(\mathrm{ONH})$, is sensitive to minute changes in blood flow and therefore very susceptible to vascular insufficiencies due to altered autoregulation, vasospasm, and systemic vascular disease. However, the process leading to non-arteritic anterior ischemic optic neuropathy (NA-AION) appears to be complex and multi-factorial (8), and the exact cause is still unknown.

\section{RISK FACTORS ASSOCIATED WITH NA-AION}

\section{SYSTEMIC CONDITIONS}

Non-arteritic anterior ischemic optic neuropathy usually occurs in the presence of an underlying vascular disease such as hypertension, diabetes, atherosclerosis, hypercholesterolemia, and regional vascular endothelial disorders, all of which predispose patients to ischemic stroke. In some cases, NA-AION is the first sign of these underlying conditions.

The role of a thrombotic tendency in NA-AION is controversial. Several studies associated elevated levels of plasma homocysteine and lipoprotein (a) and decreased levels of vitamin B6 with NA-AION (9-11), but the yield of a thrombophilic evaluation in patients with NA-AION, has not been proven $(11,12)$. Furthermore, homocysteine levels during the acute event appear to be similar in patients with NA-AION who are positive or negative for the C677T MTHFR mutation, which leads to elevated homocysteine levels (12), and a similar frequency of the MTHFR mutation was reported in patients with NA-AION and the general population (12). These findings suggest that homocysteine level and the C677T MTHFR polymorphism do not play a role in the occurrence of NA-AION.

Nocturnal hypotension has long been implicated as the "final insult" in compromised optic disk, leading to NA-AION. This assumption is based on studies showing that patients taking antihypertensive medications have a significantly lower mean nocturnal systolic blood pressure than normotensive individuals, and have a larger mean percentage decrease in systolic, diastolic, and mean blood pressures during the night (13). Others suggested that obstructive sleep apnea (OSA) may play a role in NA-AION owing to the relative ischemia that occurs during apneic episodes (14). Waller et al. (15) found that $71-89 \%$ of patients with NA-AION also had OSA, manifested by insomnia, snoring, and chronic fatigue. However, if nocturnal hypotension is indeed involved in NA-AION, the mechanism probably differs from that of OSA $(7,14,16-18)$ given findings that OSA is not associated with a nocturnal decrease in blood pressure and the lack of a difference in the mean nocturnal decrease in blood pressure between patients with NA-AION and controls (19). Arda et al. (20) proposed that sleep apnea may not be a risk factor for NA-AION by itself but rather a contributory factor given its known deleterious effect on the vascular endothelium in diabetes, hypertension, and atherosclerosis. Although OSA can be treated with continuous positive airway pressure, this may not prevent NA-AION if the causes are multifactorial (16).

\section{OPTIC DISK APPEARANCE}

A small cup-to-disk ratio ("disk-at-risk") may be a risk factor for NA-AION. A study from the University of Iowa examining 608 consecutive NA-AION patients reported a significantly smaller cup-to-disk ratio than in the general population (21), supporting earlier findings (22). A postmortem study of the optic nerve 20 days after acute presentation of NA-AION yielded no correlation between the configuration of the infarct and the vascular territory (23). The morphology was not consistent with disease of the large or small vessels and seemed to represent a form of compartment syndrome. The authors postulated that in patients with a smaller disk, compartment syndrome secondary to the $\mathrm{ONH}$ edema compresses the vasculature of the $\mathrm{ONH}$, leading to neuropathy. However, enlarged 
optic disk cup in NA-AION patient was reported (24).

\section{MEDICATIONS}

In patients with predisposing factors for NA-AION, phosphodiesterase-5 (PDE5) inhibitors used to treat erectile dysfunction, such as sildenafil, may disturb optic nerve autoregulation, leading to blood vessel dilatation and ONH edema (25). More data are still needed to corroborate this finding. Moreover, it is unclear if these effects are incidental or associated with their effects on the ocular circulation (26).

Optic neuropathy was also reported in 14 of 22 patients being treated with the antiarrhythmic drug amiodarone (27), typically bilateral. Upon discontinuation of amiodarone, only a few cases improved, all of whom had mild optic nerve dysfunction.

\section{NATURAL HISTORY OF NA-AION}

Up to $40 \%$ of NA-AION patients show spontaneous improvement in vision whereas 5-29\% experience a continued deterioration over a few days or weeks (8, 28). Following this initial phase, further progression is unusual $(28,29)$. NA-AION recurs in the affected eye in $6 \%$ of patients within 2 years and in up to $7.6 \%$ within 3 years (30-32).

\section{TREATMENT OF NA-AION}

Because the pathologic mechanism of NAAION is still unclear, suggestions for treatment are wide-ranging. None of the treatments attempted so far has proved effective in recovering the visual loss.

\section{MEDICATIONS}

Owing to its known anti-thrombotic activity, aspirin has been suggested for the treatment of patients after an initial event of NA-AION, in order to reduce the potential for hemostasis and inflammation and thereby prevent a recurrence in the fellow eye $(33,34)$. However, no significant longterm benefit was found. Nevertheless, given aspirin's proven role in treating cardiovascular risk factors, many clinicians continue to recommend it for secondary prevention of NA-AION if not contraindicated (34).

In NA-AION, compression of the optic nerve vasculature by the edematous $\mathrm{ONH}$ is believed to increase the ischemic insult and worsen the visual prognosis. Therefore, attempts to reduce the $\mathrm{ONH}$ edema in the early stages of the disease with aggressive oral or intravitreally injected steroids were carried $(2,35,36)$, but the results were disappointing. One study compared the outcome of 613 consecutive patients who voluntarily opted for either systemic corticosteroid treatment or no treatment (37). Among those with visual acuity up to 20/70 within 2 weeks of disease onset, rates of visual improvement after 6 months were $69.8 \%$ for the treated patients and $40.5 \%$ for the untreated patients. Among those with a moderate to severe initial visual field defect, corresponding rates were 40.1 and $24.5 \%$. In another trial, patients who were treated with intravitreal triamcinolone to improve $\mathrm{ONH}$ edema in the acute phase of NA-AION exhibited more improvement in visual acuity and visual field at 6 months than patients who were not (3840 ). However, none of these findings (3740) have been confirmed in a large randomized controlled trial. Indeed, in a statement on the steroid controversy in NAAION, researchers concluded that the data so far on intravitreal steroid treatment are at best anecdotal and at worst, potentially dangerous or misleading (41). Clinicians also need to take into account that corticosteroids may have significant systemic side effects, especially in elderly or vasculopathic patients (41).

The administration of bevacizumab, an anti-vascular endothelial growth factor antibody, to patients with NA-AION yielded satisfactory results in few cases (42). However, there are reports of NAION association with intravitreal bevacizumab use (43), and data from controlled randomized studies are lacking for this indication.

\section{SURGERY}

The ischemic optic neuropathy decompression study (IONDT), prompted by the compartment syndrome theory, indicated that decompression surgery was no better than careful follow-up. The $43 \%$ improvement in patients with careful follow-up as compared to $33 \%$ in the surgery group, with visual loss during the 6 months follow-up ( 12 vs. $24 \%$, respectively), revealing that decompression surgery was harmful (44).

\section{CONTROL OF RISK FACTORS}

Considering the poor results of treatments directed at the optic disk edema and inflammation associated with NAION, one of the best options at present is to control and correct any vasculopathic risk factors, such as severe hypertension, hyperglycemia, and hypercholesterolemia. Although these measures have not been proven to prevent a sequential acute event of NA-AION, they will likely improve the patients' overall health.

\section{ANIMAL MODELS OF NA-AION: THE FUTURE TARGETS OF MEDICAL TREATMENT}

Rodent and primate models of NA-AION have been developed to further understanding of the mechanisms underlying the disease (45-47). The models reproduce some signs of NA-AION across species, namely, ONH edema and loss of capillary perfusion in the optic nerve immediately behind the globe (but not in the retinal vessels), and all show long-term apoptosis of the retinal ganglion cells (RGCs) due to loss of axoplasmic transport in the damaged optic nerve $(48,49)$. The appearance of the fundus after injury in primates is very similar to that in humans, with ONH swelling and flame-like hemorrhages (49).

Rodent models of AION (rAION) have so far proved invaluable for testing potential novel treatments. Hyperbaric oxygen administered during the critical period immediately after induction of injury proved effective in preventing RGCloss (50). Intravenous or intravitreous prostaglandin J2 proffered almost equal protection when administered $5 \mathrm{~h}$ before rAION injury or immediately after, suggesting that it may have an even longer therapeutic window in humans in whom the injury develops more slowly, with episodes of recurring ONH edema $(51,52)$. Prostaglandin J2 is currently being tested in a primate model (Bernstein, 2014, personal communication). Others reported that subcutaneous granulocyte colonystimulating factor (G-CSF) had both antiapoptotic effects on the RGCs and antiinflammatory effects on the optic nerve (53). Experiments in models of optic nerve crush (ONC), which induces severe edema in the $\mathrm{ONH}$ while allowing for examination of loss of microvascular perfusion and RGC death, show a protective effect of G-CSF when administered after injury $(54,55)$. 
Clinical findings on the benefit of bevacizumab were supported in a murine model of ONC, showing that the drug preserved the integrity of the microvasculature (56). This apparently prevented post-ONC ischemia from spreading from the site of injury to the immediate retrobulbar portion of the nerve. Accordingly, experimental studies of intravitreal brimonidine, a peripherally acting $\alpha 2$ adrenergic agonist, reported an increase in short-term RGC survival after ONC (57). However, this effect is paradoxical: in glaucoma, brimonidine was found to reduce aqueous humor production by inducing vasoconstriction, whereas in rAION, the decreased RGC loss would be expected to be secondary to improved perfusion. Furthermore, a study conducted to evaluate the effects of brimonidine on AION revealed worse vision in those who received brimonidine (58). Therefore, brimonidine in the ONC setting may promote axonal growth (59) rather than affect vasoactivity, protect the RGCs in conditions of elevated intraocular pressure (60), and increase levels of brainderived neurotrophic factor (BDNF) (61). There are as yet no studies of the effect of brimonidine on the oligodendrocytes, which are necessary for optic nerve axonal health and are directly injured by ONC. Brimonidine may be generally protective when axonal regrowth is required after rAION.

It is noteworthy, however, that findings of enhanced RGC survival after rAION (62) following pretreatment with brimonidine were not replicated in models of NA-AION $(58,63)$. Furthermore, the sudden onset of NA-AION and the typically delayed diagnosis make brimonidine pretreatment for NA-AION impractical, although translating from bench to clinic, brimonidine might be used prophylactically in the fellow unaffected eye of patients with NA-AION.

High doses of estrogen (64) were found to have no therapeutic value in rAION, compatible with the lack of gender specificity in NA-AION outcome, although women are considered protected until menopause.

Aside from G-CSF $(54,55)$, other exogenous compounds were found to have a protective effect against some aspects of ONC when administered after injury, including $\alpha$-crystallin (65), BDNF (66-68), the
PPAR $\gamma$ agonist pioglitazone (69), the sirtuin 1 (SIRT1) agonist resveratrol (70), pigment epithelial-derived growth factor (PEDF) (71), Toll-like receptor 4 (TLR4) antagonists (72), valproate (73), and endothelin-B antagonists (74). There is an even larger army of available drugs for potential pretreatment in ONC injury. Overall, they are directed against reducing inflammation or its signaling molecules, promoting survival or repair of damaged axons, or preserving patency of the blood supply. Almost none have been clinically tested.

\section{SUMMARY}

There is still no widely recognized treatment for NA-AION. Evidence from animal models of NA-AION generally suggests that reducing edema and inflammation in the acute phase might be effective. Intravitreal injections are becoming more commonly used.

The availability of drugs and the direct approach into the eye may be the best approach to therapy during the acute phase, allowing support for the injured RGCs. Improving RGC survival and reducing axonal damage after NA-AION is an active topic of investigation, directing future goals of neuronal regeneration or retinal neurogenesis. Cellular therapy, either by systemic transplantation or intravitreous administration, might become the next mode of treatment to improve visual outcome in NA-AION.

\section{ACKNOWLEDGMENTS}

This work was supported in part by the Zanvyl and Isabelle Krieger Fund, Baltimore, MD, USA (NGC); Israel Science Foundation 1189/12 (NGC).

\section{REFERENCES}

1. Hayreh SS. Ischemic optic neuropathy. Prog Retin Eye Res (2009) 28(1):34-62. doi:10.1016/j. preteyeres.2008.11.002

2. Hayreh SS. Ischemic optic neuropathies - where are we now? Graefes Arch Clin Exp Ophthalmol (2013) 251(8):1873-84. doi:10.1007/s00417-0132399-z

3. Banik R. Nonarteritic anterior ischemic optic neuropathy: an update on demographics, clinical presentation, pathophysiology, animal models, prognosis, and treatment. JClin Exp Ophthalmol (2013) S3:004. doi:10.4172/2155-9570.S3-004

4. Luneau K, Newman NJ, Biousse V. Ischemic optic neuropathies. Neurologist (2008) 14(6):341-54. doi:10.1097/NRL.0b013e318177394b
5. Hayreh SS. Ocular vascular occlusive disorders: natural history of visual outcome. Prog Retin Eye Res (2014) 41C:1-25. doi:10.1016/j.preteyeres. 2014.04.001

6. Steigerwalt RD Jr, Cesarone MR, Belcaro G, Pascarella A, De Angelis M, Gattegna R, et al. Arteritic anterior ischemic optic neuropathy treated with intravenous prostaglandin $\mathrm{E}(1)$ and steroids. Int $J$ Angiol (2010) 19(3):e113-5. doi:10.1055/s-00311278380

7. Zhang C, Guo Y, Miller NR, Bernstein SL. Optic nerve infarction and post-ischemic inflammation in the rodent model of anterior ischemic optic neuropathy (rAION). Brain Res (2009) 1264:67-75. doi:10.1016/j.brainres.2008.12.075

8. Hayreh SS, Zimmerman MB. Nonarteritic anterior ischemic optic neuropathy: natural history of visual outcome. Ophthalmology (2008) 115(2):298-305. doi:10.1016/j.ophtha.2007.05.027

9. Giambene B, Sodi A, Sofi F, Marcucci R, Fedi S, Abbate R, et al. Evaluation of traditional and emerging cardiovascular risk factors in patients with non-arteritic anterior ischemic optic neuropathy: a case-control study. Graefes Arch Clin Exp Ophthalmol (2009) 247(5):693-7. doi:10.1007/ s00417-008-0981-6

10. Salomon O, Huna-Baron R, Kurtz S, Steinberg DM, Moisseiev J, Rosenberg N, et al. Analysis of prothrombotic and vascular risk factors in patients with nonarteritic anterior ischemic optic neuropathy. Ophthalmology (1999) 106(4):739-42. doi:10. 1016/S0161-6420(99)90159-8

11. Kawasaki A, Purvin VA, Burgett RA. Hyperhomocysteinaemia in young patients with non-arteritic anterior ischaemic optic neuropathy. $\mathrm{Br} J \mathrm{Oph}$ thalmol (1999) 83(11):1287-90. doi:10.1136/bjo. 83.11.1287

12. Biousse V, Kerrison JB, Newman NJ. Is nonarteritic anterior ischaemic optic neuropathy related to homocysteine? Br J Ophthalmol (2000) 84(5):555. doi:10.1136/bjo.84.5.554c

13. Hayreh SS, Podhajsky P, Zimmerman MB. Role of nocturnal arterial hypotension in optic nerve head ischemic disorders. Ophthalmologica (1999) 213(2):76-96. doi:10.1159/000027399

14. Archer EL, Pepin S. Obstructive sleep apnea and nonarteritic anterior ischemic optic neuropathy: evidence for an association. J Clin Sleep Med (2013) 9(6):613-8. doi:10.5664/jcsm.2766

15. Waller EA, Bendel RE, Kaplan J. Sleep disorders and the eye. Mayo Clin Proc (2008) 83(11):1251-61. doi: $10.4065 / 83.11 .1251$

16. Behbehani R, Mathews MK, Sergott RC, Savino PJ. Nonarteritic anterior ischemic optic neuropathy in patients with sleep apnea while being treated with continuous positive airway pressure. Am J Ophthalmol (2005) 139(3):518-21. doi:10.1016/j.ajo. 2004.11.004

17. Bilgin G, Koban Y, Arnold AC. Nonarteritic anterior ischemic optic neuropathy and obstructive sleep apnea. J Neuroophthalmol (2013) 33(3):232-4. doi:10.1097/WNO.0b013e31828eecbd

18. Kolb SD, Backhouse O. Obstructive sleep apnoea prevalence in non-arteritic anterior ischaemic optic neuropathy: a response. $\mathrm{Br} J$ Ophthalmol (2013) 97(6):794. doi:10.1136/bjophthalmol2013-303179 
19. Landau K, Winterkorn JM, Mailloux LU, Vetter W, Napolitano B. 24-Hour blood pressure monitoring in patients with anterior ischemic optic neuropathy. Arch Ophthalmol (1996) 114(5):570-5. doi:10.1001/archopht.1996.01100130562012

20. Arda H, Birer S, Aksu M, Ismailogullari S, Karakucuk S, Mirza E, et al. Obstructive sleep apnoea prevalence in non-arteritic anterior ischaemic optic neuropathy. $\mathrm{Br} J$ Ophthalmol (2013) 97(2):206-9. doi:10.1136/bjophthalmol2012-302598

21. Hayreh SS, Zimmerman MB. Nonarteritic anterior ischemic optic neuropathy: refractive error and its relationship to cup/disc ratio. Ophthalmology (2008) 115(12):2275-81. doi:10.1016/j. ophtha.2008.08.007

22. Burde RM. Optic disk risk factors for nonarteritic anterior ischemic optic neuropathy. Am J Ophthalmol (1993) 116(6):759-64.

23. Tesser RA, Niendorf ER, Levin LA. The morphology of an infarct in nonarteritic anterior ischemic optic neuropathy. Ophthalmology (2003) 110(10):2031-5. doi:10.1016/S01616420(03)00804-2

24. Parsa CF, Muci-Mendoza R, Hoyt WF. Anterior ischemic optic neuropathy in a disc with a cup: an exception to the rule. JNeuroophthalmol (1998) 18(3):169-70. doi:10.1097/00041327-19980900000003

25. Hayreh SS. Non-arteritic anterior ischaemic optic neuropathy and phosphodiesterase-5 inhibitors. Br J Ophthalmol (2008) 92(12):1577-80. doi:10. 1136/bjo.2008.149013

26. Laties AM. Vision disorders and phosphodiesterase type 5 inhibitors: a review of the evidence to date. Drug Saf (2009) 32(1):1-18. doi:10.2165/ 00002018-200932010-00001

27. Purvin V, Kawasaki A, Borruat FX. Optic neuropathy in patients using amiodarone. Arch Ophthalmol (2006) 124(5):696-701. doi:10.1001/ archopht.124.5.696

28. Arnold AC, Hepler RS. Natural history of nonarteritic anterior ischemic optic neuropathy. J Neuroophthalmol (1994) 14(2):66-9. doi:10.1097/ 00041327-199406000-00002

29. Kernstock C, Beisse F, Wiethoff S, Mast A, Krapp E, Grund R, et al. Assessment of functional and morphometric endpoints in patients with non-arteritic anterior ischemic optic neuropathy (NAION). Graefes Arch Clin Exp Ophthalmol (2014) 252(3):515-21. doi:10.1007/s00417014-2572-z

30. Kao LY, Huang L, Chen TT. Anterior ischemic optic neuropathy - recurrent attacks in one eye in a bilateral case. Ann Ophthalmol (1989) 21(2):71-4.

31. Rucker JC, Biousse V, Newman NJ. Ischemic optic neuropathies. Curr Opin Neurol (2004) 17(1):27-35. doi:10.1097/00019052-20040200000006

32. Preechawat P, Bruce BB, Newman NJ, Biousse V. Anterior ischemic optic neuropathy in patients younger than 50 years. Am J Ophthalmol (2007) 144(6):953-60. doi:10.1016/j.ajo.2007.07.031

33. Kupersmith MJ, Frohman L, Sanderson M, Jacobs J, Hirschfeld J, Ku C, et al. Aspirin reduces the incidence of second eye NAION: a retrospective study. J Neuroophthalmol (1997) 17(4):250-3. doi:10.1097/00041327-199712000-00007
34. Atkins EJ. Nonarteritic anterior ischemic optic neuropathy. Curr Treat Options Neurol (2011) 13(1):92-100. doi:10.1007/s11940-010-0099-0

35. Hayreh SS. Management of ischemic optic neuropathies. Indian J Ophthalmol (2011) 59(2):123-36. doi:10.4103/0301-4738.77024

36. Modarres M, Falavarjani KG, Nazari H, Sanjari MS, Aghamohammadi F, Homaii M, et al. Intravitreal erythropoietin injection for the treatment of nonarteritic anterior ischaemic optic neuropathy. $\mathrm{Br}$ J Ophthalmol (2011) 95(7):992-5. doi:10.1136/bjo. 2010.191627

37. Hayreh SS, Zimmerman MB. Non-arteritic anterior ischemic optic neuropathy: role of systemic corticosteroid therapy. Graefes Arch Clin Exp Ophthalmol (2008) 246(7):1029-46. doi:10.1007/ s00417-008-0805-8

38. Radoi C, Garcia T, Brugniart C, Ducasse A, Arndt C. Intravitreal triamcinolone injections in non-arteritic anterior ischemic optic neuropathy. Graefes Arch Clin Exp Ophthalmol (2014) 252(2):339-45. doi:10.1007/s00417-013-2499-9

39. Sohn BJ, Chun BY, Kwon JY. The effect of an intravitreal triamcinolone acetonide injection for acute nonarteritic anterior ischemic optic neuropathy. Korean J Ophthalmol (2009) 23(1):59-61. doi:10.3341/kjo.2009.23.1.59

40. Yaman A, Selver OB, Saatci AO, Soylev MF. Intravitreal triamcinolone acetonide injection for acute non-arteritic anterior ischaemic optic neuropathy. Clin Exp Optom (2008) 91(6):561-4. doi:10.1111/ j.1444-0938.2008.00287.x

41. Lee AG, Biousse V. Should steroids be offered to patients with nonarteritic anterior ischemic optic neuropathy? J Neuroophthalmol (2010) 30(2):193-8. doi:10.1097/WNO.0b013e3181e1f71f

42. Bennett JL, Thomas S, Olson JL, Mandava N. Treatment of nonarteritic anterior ischemic optic neuropathy with intravitreal bevacizumab. J Neuroophthalmol (2007) 27(3):238-40. doi:10.1097/ WNO.0b013e31814b273d

43. Huang JY, Ozaki H, Hayashi H, Uchio E. Anterior ischemic optic neuropathy following intravitreal bevacizumab. Jpn J Ophthalmol (2010) 54:252-4. doi:10.1007/s10384-009-0790-4

44. Ischemic Optic Neuropathy Decompression Trial Research Group. Ischemic optic neuropathy decompression trial: twenty-four-month update. Arch Ophthalmol (2000) 118(6):793-8. doi:10. 1001/archopht.118.6.793

45. Goldenberg-Cohen N, Guo Y, Margolis F, Cohen Y, Miller NR, Bernstein SL. Oligodendrocyte dysfunction after induction of experimental anterior optic nerve ischemia. Invest Ophthalmol Vis Sci (2005) 46(8):2716-25. doi:10.1167/iovs.04-0547

46. Bernstein SL, Guo Y, Kelman SE, Flower RW, Johnson MA. Functional and cellular responses in a novel rodent model of anterior ischemic optic neuropathy. Invest Ophthalmol Vis Sci (2003) 44(10):4153-62. doi:10.1167/iovs.03-0274

47. Chen CS, Johnson MA, Flower RA, Slater BJ, Miller NR, Bernstein SL. A primate model of nonarteritic anterior ischemic optic neuropathy. Invest Ophthalmol Vis Sci (2008) 49(7):2985-92. doi:10.1167/ iovs.07-1651

48. Bernstein SL, Russell P, Wong P, Fishelevich R, Smith LE. Heat shock protein 90 in retinal ganglion cells: association with axonally transported proteins. Vis Neurosci (2001) 18(3):429-36. doi:10. 1017/S0952523801183094

49. Bernstein SL, Johnson MA, Miller NR. Nonarteritic anterior ischemic optic neuropathy (NAION) and its experimental models. Prog Retin Eye Res (2011) 30(3):167-87. doi:10.1016/j.preteyeres. 2011.02.003

50. Avraham-Lubin BC, Dratviman-Storobinsky O, El SD, Hasanreisoglu M, Goldenberg-Cohen N. Neuroprotective effect of hyperbaric oxygen therapy on anterior ischemic optic neuropathy. Front Neurol (2011) 2:23. doi:10.3389/fneur.2011.00023

51. Nicholson JD, Puche AC, Guo Y, Weinreich D, Slater BJ, Bernstein SL. PGJ(2) provides prolonged CNS stroke protection by reducing white matter edema. PLoS One (2012) 7(12):e50021. doi:10. 1371/journal.pone.0050021

52. Touitou V, Johnson MA, Guo Y, Miller NR, Bernstein SL. Sustained neuroprotection from a single intravitreal injection of PGJ2 in a rodent model of anterior ischemic optic neuropathy. Invest Ophthalmol Vis Sci (2013) 54(12):7402-9. doi:10.1167/ iovs.13-12055

53. Chang CH, Huang TL, Huang SP, Tsai RK. Neuroprotective effects of recombinant human granulocyte colony-stimulating factor (G-CSF) in a rat model of anterior ischemic optic neuropathy (rAION). Exp Eye Res (2014) 118:109-16. doi:10.1016/j.exer.2013.11.012

54. Tsai RK, Chang CH, Wang HZ. Neuroprotective effects of recombinant human granulocyte colonystimulating factor (G-CSF) in neurodegeneration after optic nerve crush in rats. Exp Eye Res (2008) 87(3):242-50. doi:10.1016/j.exer.2008.06.004

55. Tsai RK, Chang CH, Sheu MM, Huang ZL. Antiapoptotic effects of human granulocyte colonystimulating factor (G-CSF) on retinal ganglion cells after optic nerve crush are PI3K/AKTdependent. Exp Eye Res (2010) 90(5):537-45. doi: 10.1016/j.exer.2010.01.004

56. Rappoport D, Morzaev D, Weiss S, Vieyra M, Nicholson JD, Leiba H, et al. Effect of intravitreal injection of bevacizumab on optic nerve head leakage and retinal ganglion cell survival in a mouse model of optic nerve crush. Invest Ophthalmol Vis Sci (2013) 54(13):8160-71. doi:10.1167/iovs.1312771

57. Dai Y, Lindsey JD, Duong-Polk KX, Chindasub P, Leung CK, Weinreb RN. Brimonidine protects against loss of Thy-1 promoter activation following optic nerve crush. BMC Ophthalmol (2013) 13(1):26. doi:10.1186/1471-2415-13-26

58. Fazzone HE, Kupersmith MJ, Leibmann J. Does topical brimonidine tartrate help NAION? $\mathrm{Br} J$ Ophthalmol (2003) 87(9):1193-4. doi:10.1136/bjo. 87.9.1193

59. Fujita Y, Sato A, Yamashita T. Brimonidine promotes axon growth after optic nerve injury through ERK phosphorylation. Cell Death Dis (2013) 4:e763. doi:10.1038/cddis.2013.298

60. Lambert WS, Ruiz L, Crish SD, Wheeler LA, Calkins DJ. Brimonidine prevents axonal and somatic degeneration of retinal ganglion cell neurons. $\mathrm{Mol}$ Neurodegener (2011) 6(1):4. doi:10.1186/17501326-6-4

61. Gao H, Qiao X, Cantor LB, WuDunn D. Upregulation of brain-derived neurotrophic factor 
expression by brimonidine in rat retinal ganglion cells. Arch Ophthalmol (2002) 120(6):797-803. doi:10.1001/archopht.120.6.797

62. Goldenberg-Cohen N, Dadon-Bar-El S, Hasanreisoglu M, Avraham-Lubin BC, DratvimanStorobinsky O, Cohen Y, et al. Possible neuroprotective effect of brimonidine in a mouse model of ischaemic optic neuropathy. Clin Experiment Ophthalmol (2009) 37(7):718-29. doi:10.1111/j.14429071.2009.02108.x

63. Wilhelm B, Lüdtke H, Wilhelm H, Group BS, Efficacy and tolerability of $0.2 \%$ brimonidine tartrate for the treatment of acute non-arteritic anterior ischemic optic neuropathy (NAION): a 3-month, double-masked, randomised, placebocontrolled trial. Graefes Arch Clin Exp Ophthalmol (2006) 244(5):551-8. doi:10.1007/s00417005-0102-8

64. Bernstein SL, Mehrabyan Z, Guo Y, Moianie N. Estrogen is not neuroprotective in a rodent model of optic nerve stroke. Mol Vis (2007) 13:1920-5. Availabel at: http://www.molvis.org/molvis/v13/ a216/

65. Wu N, Yu J, Chen S, Xu J, Ying X, Ye M, et al. $\alpha$-Crystallin protects RGC survival and inhibits microglial activation after optic nerve crush. Life Sci (2014) 94(1):17-23. doi:10.1016/j.lfs.2013.10. 034

66. Weibel D, Kreutzberg GW, Schwab ME. Brainderived neurotrophic factor (BDNF) prevents lesion-induced axonal die-back in young rat optic nerve. Brain Res (1995) 679(2):249-54. doi:10. 1016/0006-8993(95)00238-L
67. Chen H, Weber AJ. BDNF enhances retinal ganglion cell survival in cats with optic nerve damage. Invest Ophthalmol Vis Sci (2001) 42(5):966-74.

68. Weber AJ, Viswanáthan S, Ramanathan C, Harman $\mathrm{CD}$. Combined application of BDNF to the eye and brain enhances ganglion cell survival and function in the cat after optic nerve injury. Invest Ophthalmol Vis Sci (2010) 51(1):327-34. doi:10.1167/iovs. 09-3740

69. Zhu J, Zhang J, Ji M, Gu H, Xu Y, Chen C, et al. The role of peroxisome proliferator-activated receptor and effects of its agonist, pioglitazone, on a rat model of optic nerve crush: PPAR $\gamma$ in retinal neuroprotection. PLoS One (2013) 8(7):e68935. doi:10.1371/journal.pone.0068935

70. Zuo L, Khan RS, Lee V, Dine K, Wu W, Shindler KS. SIRT1 promotes RGC survival and delays loss of function following optic nerve crush. Invest Ophthalmol Vis Sci (2013) 54(7):5097-102. doi:10. 1167/iovs.13-12157

71. Vigneswara V, Berry M, Logan A, Ahmed Z. Pigment epithelium-derived factor is retinal ganglion cell neuroprotective and axogenic after optic nerve crush injury. Invest Ophthalmol Vis Sci (2013) 54(4):2624-33. doi:10.1167/iovs.13-11803

72. Zheng Z, Yuan R, Song M, Huo Y, Liu W, Cai X, et al. The Toll-like receptor 4-mediated signaling pathway is activated following optic nerve injury in mice. Brain Res (2012) 1489:90-7. doi:10.1016 j.brainres.2012.10.014

73. Zhang ZZ, Gong YY, Shi YH, Zhang W, Qin XH, Wu XW. Valproate promotes survival of retinal ganglion cells in a rat model of optic nerve crush. Neuroscience (2012) 224:282-93. doi:10. 1016/j.neuroscience.2012.07.056

74. Tonari $\mathrm{M}$, Kurimoto $\mathrm{T}$, Horie $\mathrm{T}$, Sugiyama $\mathrm{T}$, Ikeda $\mathrm{T}$, Oku H. Blocking endothelin-B receptors rescues retinal ganglion cells from optic nerve injury through suppression of neuroinflammation. Invest Ophthalmol Vis Sci (2012) 53(7):3490-500. doi:10.1167/iovs.11-9415

Conflict of Interest Statement: The authors declare that the research was conducted in the absence of any commercial or financial relationships that could be construed as a potential conflict of interest.

Received: 24 February 2014; accepted: 25 June 2014; published online: 11 July 2014.

Citation: Nicholson JD, Leiba H and Goldenberg-Cohen $N$ (2014) Translational preclinical research may lead to improved medical management of non-arteritic anterior ischemic optic neuropathy. Front. Neurol. 5:122. doi: 10.3389/fneur.2014.00122

This article was submitted to Neuro-Ophthalmology, a section of the journal Frontiers in Neurology.

Copyright () 2014 Nicholson, Leiba and GoldenbergCohen. This is an open-access article distributed under the terms of the Creative Commons Attribution License (CC BY). The use, distribution or reproduction in other forums is permitted, provided the original author(s) or licensor are credited and that the original publication in this journal is cited, in accordance with accepted academic practice. No use, distribution or reproduction is permitted which does not comply with these terms. 